\title{
DO ONLINE AND FACE-TO-FACE STUDENTS EXHIBIT THE SAME INFORMATION ANALYSIS SKILLS?
}

\author{
Nelbert C. St. Clair, Middle Georgia State University, nelbert.stclair@mga.edu \\ John P. Girard, Middle Georgia State University,john.girard@mga.edu
}

\begin{abstract}
This paper chronicles the findings of a five-year project that investigated the differences in student learning based on mode of delivery (online and face-to-face). During each of the comparison years, there was a single online section and a single face-to-face section of the same management capstone class. All classes were facilitated by the same professor. There were no significant differences in skills amongst online and face-to-face students.
\end{abstract}

Keywords: Online, Face-to-face, Innovation, Technology, Critical Thinking, Information Analysis

\section{INTRODUCTION}

Aim

Educators, policy makers, parents and other stakeholders across the country struggle with the question Do significant differences exist amongst online and face-to-face students? This project builds on the solid foundation of previous research to explore this age-old question.

The catalyst for this research was a review of data from two 2014 senior capstone classes, one fully online and the other face-to-face, which highlighted some interesting findings. Figure 1 shows the scores achieved by students from a group of 18 questions associated with the goal titled Interpret and Analyze Accounting Information. The visual review seemed to indicate a difference between online and face-to-face students. A t-test determined that face-to-face students scored higher $(M=135.72)$ than online students $(M=100.13)$. This difference was significant at the .05 critical alpha level; $\mathrm{t}(32)=3.03, \mathrm{p}=0.00)$.

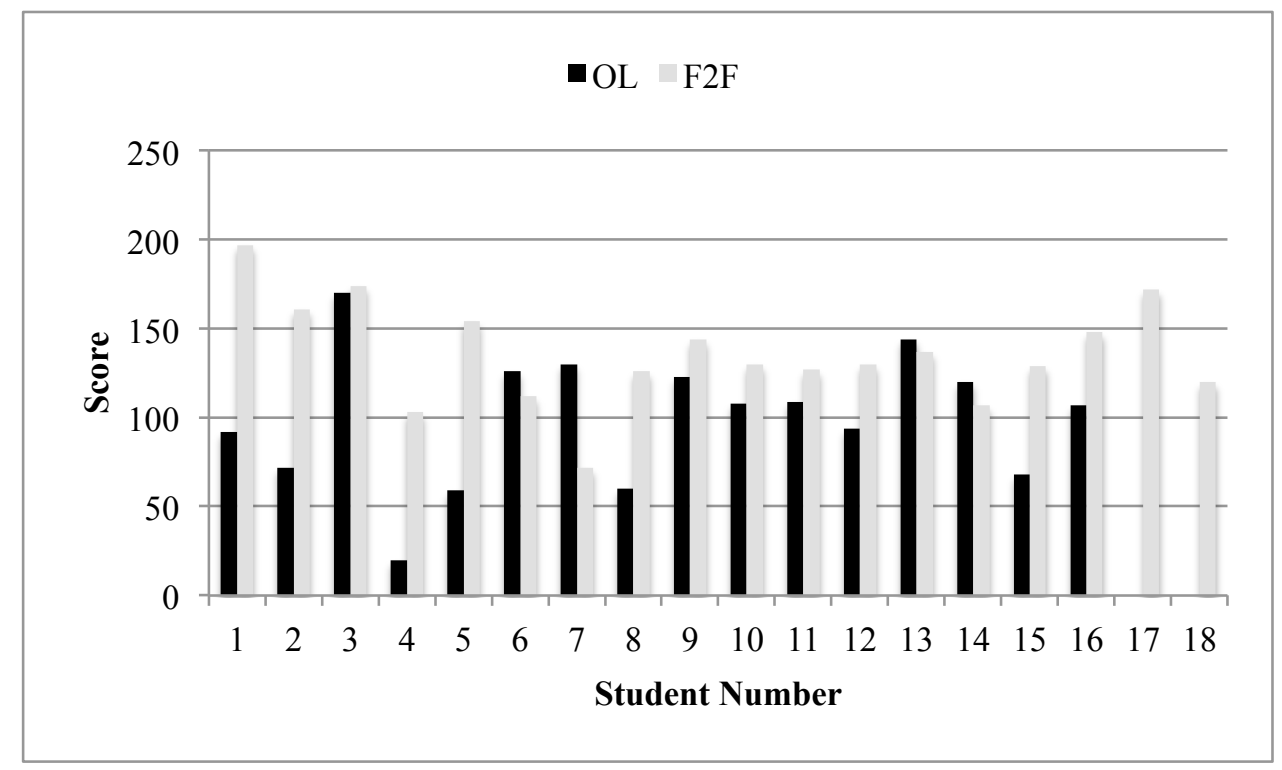

Figure 1. Interpret and Analyze Accounting Data 
Although promising, it was clear that this initial analysis was insufficient to draw conclusions or to generalize groups of students. The ultimate purpose of this research was to determine if difference existed in the analysis skills of online and face-to-face students.

To achieve this aim, we commence with a brief review of face-to-face and online education as it applies to this project. Next, we consider the important concept of critical thinking, as we believe this is an essential skill for students as they consider the tasks of interrupting and analyzing data, innovation and the use of technology. After establishing this baseline the precise definitions used for the four hypotheses are described. In the penultimate section we highlight the results and finally we offer our conclusions.

\section{Face-to-Face Versus Online Education}

For this project, we define a face-to-face course as traditional in class or "brick-and-mortar" learning, synchronous learning, where the student listens to a lecture from the professor. An online course is defined as the course content being delivered via Internet through a learning management system (LMS), asynchronous learning, where the student logs on at their leisure and does not attend class lectures.

The demand for online courses are increasing at a growth rate of $6.1 \%$ and over 7 million students are enrolled in an online course at a college or university [1]. The traditional brick-and-mortar degrees and diplomas are now being compared to online degrees and diplomas. Research on student ratings of Face-to-Face versus Online Courses discovered there is no difference between the two $[2,7]$. The chart below describes the activities between a face-toface versus online course [16].

Table 1. Alignment of Face-to-Face Activities with Online Equivalents [16]

\begin{tabular}{|c|c|}
\hline $\begin{array}{l}\text { Face-to-Face Activities } \\
\text { Fla }\end{array}$ & $\begin{array}{c}\text { Online Activities } \\
\text { Studente read the teythook }\end{array}$ \\
\hline $\begin{array}{l}\text { Class lecture } \\
\text { In the face-to-face classroom students are passive } \\
\text { listeners. Later they study at home and read the textbook } \\
\text { and other assigned materials }\end{array}$ & $\begin{array}{l}\text { Students read the textbook, study PowerPoint lecture } \\
\text { files, read the annotations } \\
\text { When studying at home students spend time reading } \\
\text { the textbook and other assigned materials }\end{array}$ \\
\hline Timed tests & Timed tests \\
\hline $\begin{array}{l}\text { Essay } \\
\text { Students learn from each other, each student's research } \\
\text { benefits the entire class }\end{array}$ & $\begin{array}{l}\text { Discussions may be considered an equivalent of the } \\
\text { essay } \\
\text { Students do not have an opportunity to learn from } \\
\text { their peers' research }\end{array}$ \\
\hline $\begin{array}{l}\text { Class Discussions } \\
\text { Not every student participates } \\
\text { Discussions end when class ends } \\
\text { Students can use only words } \\
\text { In the best case each student participates once. } \\
\text { There are some "vocal" students who dominate the } \\
\text { classroom and some shy students who rarely participate } \\
\text { Weak student-student interaction } \\
\text { Students informally communicate before and after class } \\
\text { Instructor has very little knowledge of his students' } \\
\text { problems and personal situation } \\
\text { Students are not comfortable talking }\end{array}$ & $\begin{array}{l}\text { Discussion board assignments } \\
\text { Each student is required to participate by posting an } \\
\text { initial discussion } \\
\text { Discussions do not have to end when class ends, they } \\
\text { start in the beginning of the week and end when the } \\
\text { week is over } \\
\text { Students can return to the same topic and participate } \\
\text { during the entire week } \\
\text { Students have time to conduct research and post } \\
\text { visual materials to clarify their ideas } \\
\text { Since the online classroom provides more anonymity } \\
\text { it is easier for every student to express thoughts } \\
\text { Very strong student-student interaction } \\
\text { Students communicate with each other any time using } \\
\text { the "Tea Room" } \\
\text { Students share their problems and are open about their } \\
\text { personal situations } \\
\text { Students are more comfortable texting than talking }\end{array}$ \\
\hline
\end{tabular}




\section{Critical Thinking}

Critical thinking (CT) is defined as "mode of thinking — about any subject, content, or problem — in which the thinker improves the quality of his or her thinking by skillfully analyzing, assessing, and reconstructing it. Critical thinking is self-directed, self-disciplined, self-monitored, and self-corrective thinking [5]." Halpern [8] refers to CT as "use of cognitive skills or strategies that increase the probability of a desirable outcome." Other researchers have also defined critical thinking as problem solving, Mayer [11]. This approach is "understanding of the cognition side of cognitive psychology [11]." Dawes [4] compares decision-making to critical thinking which enables students thinking and learning about the principles of rationale and how to apply it in the decision-making model. Rabinowitz [14] cognitive process is also a broad definition of critical thinking. Research has shown that academic background has no effect on the approach and how the skills of critical thinking can be applied to help foster or enable a critical thinker [8].

King [10] advocated that critical thinking consist of skills and the process of analyzing the presented "arguments, making inferences, drawing logical conclusions, and critically evaluating all relevant elements as well as the possible consequences of each decision [9]." Paul and Elder [13] emphasized critical thinking should be incorporated into every online course, this can enhance discussions in a virtual classroom meanwhile the students are conveying information in an organized manner. There is growing concensious that the goal of critical thinking is to generate or develop individual thinking skills and be able to apply those skills to any given situation [13].

Ricci [15] emphasizes critical thinking at the physical level in the classroom because of the environment or the make-up of the classroom. An instructor could use visual aids and seating charts to create critical thinking in classroom. The physical reactions of the instructor could prompt the students to interact and figure out what the instructor is trying to relay to the class [15].

Researchers have compared critical thinking skills of online and face-to-face courses, and analyzed student achievements before and after. They used the California Critical Thinking Skills Test (CCTST) and compared critical thinking assignments, which was a required part of the course. The end result of this study was no significant difference found between online students versus face-to-face students in the area of critical thinking [6].

\section{RESEARCH METHODOLOGY}

This research centered upon the following research question: Do significant skill differences exist amongst online and face-to-face students in the United States?

The research hypotheses to be tested are as follows:

$\mathrm{H}_{1}$ : Online and face-to-face students have the same critical thinking skills

$\mathrm{H}_{2}$ : Online and face-to-face students have the same innovation and technology skills

$\mathrm{H}_{3}$ : Online and face-to-face students have the same management use of information skills

$\mathrm{H}_{4}$ : Online and face-to-face students have the same ability to interpret and analyze accounting information

To test these hypotheses the researchers analyzed student results from a management capstone course final assessment. The data was collected from five semesters (10 sections) during the period 2009 to 2014 . During each semester there was a single online section and a single face-to-face section. The number of students in each section ranged from 12 to 24 with a mean of 16.72. In total, the results of 166 students were analyzed: 82 online and 84 face-to-face.

To ensure the comparison year on year is valid, the research only considered students from a single professor. In other words all 10 sections received the same instruction from the same professor thus eliminating the variance that exists between instructors. 
The final course assessment included 40 questions that remained constant through the period. The assessment tool was designed to measure student achievement in a variety of program goals. This project uses the definitions established in the CompXM Assurance of Learning Guide [3]:

- Innovation and technology: Develop graduates who can foster innovation in organizations, respond effectively to new circumstances; and through their actions, enable organizations and society to realize the potential of new technologies.

- Management use of information: Develop graduates with the capability to organize, describe, and make intelligent inferences from empirical evidence. Graduates should be able to apply sophisticated statistical techniques to data; make informed forecasts of business trends; and formulate, solve, and interpret quantitative business decision models.

- Interpret and analyze accounting information for internal control, planning, performance evaluation, and coordination to continuously improve business processes.

- Critical thinking skills: Critically evaluate, analyze and interpret information to solve problems and make business decisions. Students will interpret and evaluate unstructured situations, define the problem, apply theories to ambiguous situations, draw conclusions and implement solutions.

\section{RESULTS}

For each of the four hypotheses a visual inspection of the data preceded a two-tail t-test to determine if a statistically significant difference existed between the online and face-to-face students. The first hypothesis tested whether online and face-to-face students have the same critical thinking skills (see Figure 2). Online students scored lower $(M=207.01)$ than face-to-face students $(M=216.65)$, but the difference was not significant at the .05 critical alpha level; $\mathrm{t}(8)=0.95, \mathrm{p}=0.1853$. Therefore we fail to reject the null hypothesis and conclude that the difference between online and face-to-face students was not significant.

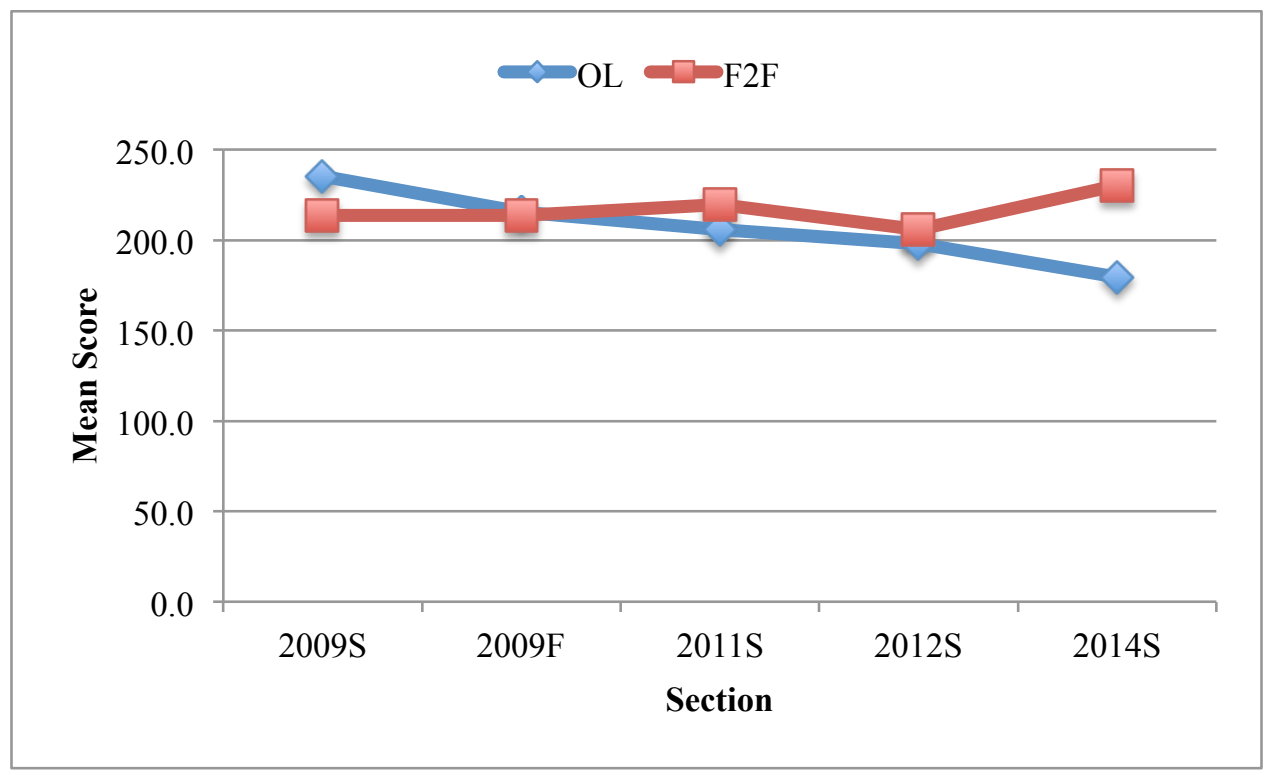

Figure 2 - H1. Critical Thinking Skills

The second hypothesis tested whether online and face-to-face students have the same innovation and technology skills (see Figure 3$)$. Online students scored lower $(M=72.38)$ than face-to-face students $(M=73.78)$, but the difference was not significant at the .05 critical alpha level; $\mathrm{t}(8)=0.36, \mathrm{p}=0.7258$. Therefore we fail to reject the null hypothesis and conclude that the difference between online and face-to-face students was not significant. 


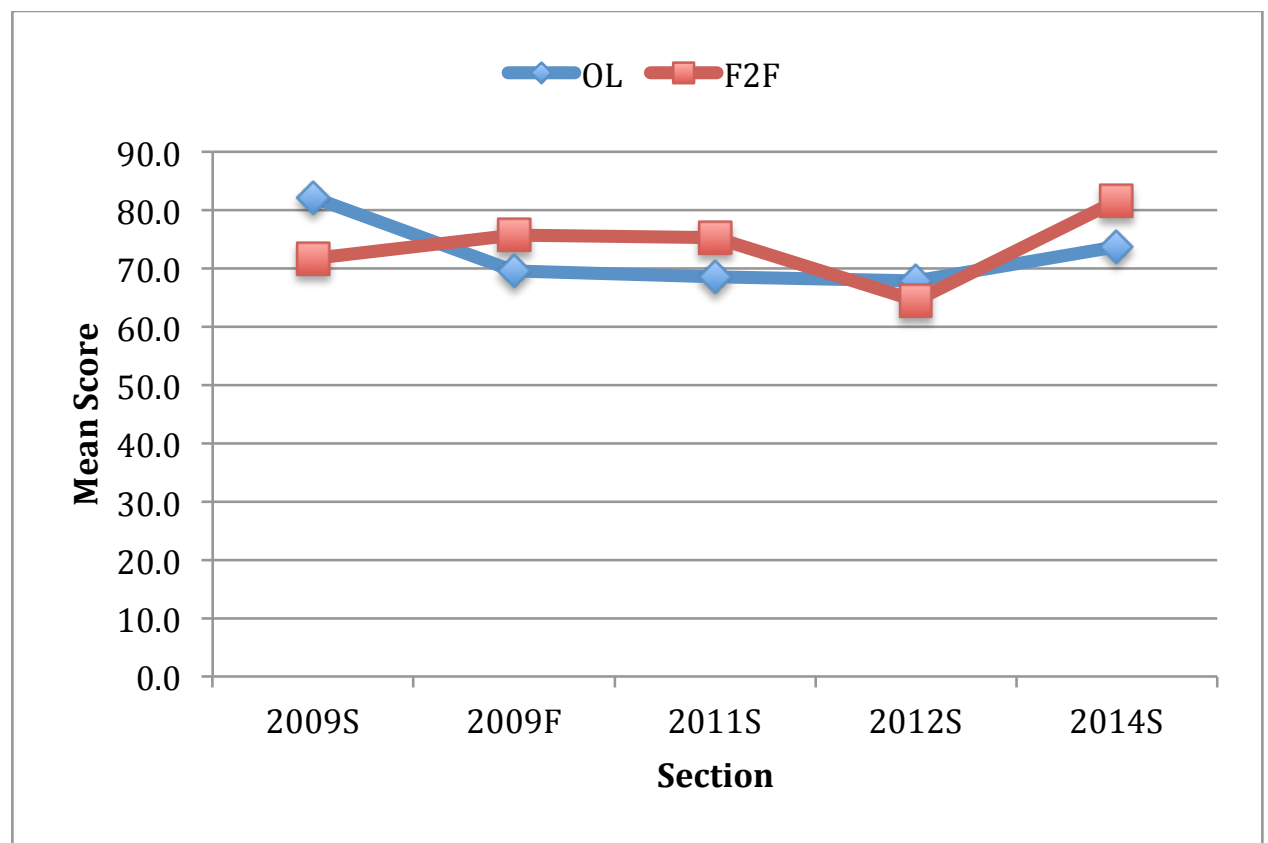

Figure 3 - H2. Innovation and Technology

The third hypothesis tested whether online and face-to-face students have the same management use of information skills (see Figure 4). Online students scored lower $(M=139.12)$ than face-to-face students $(M=141.96)$, but the difference was not significant at the .05 critical alpha level; $t(8)=0.37, p=0.7231$. Therefore we fail to reject the null hypothesis and conclude that the difference between online and face-to-face students was not significant.

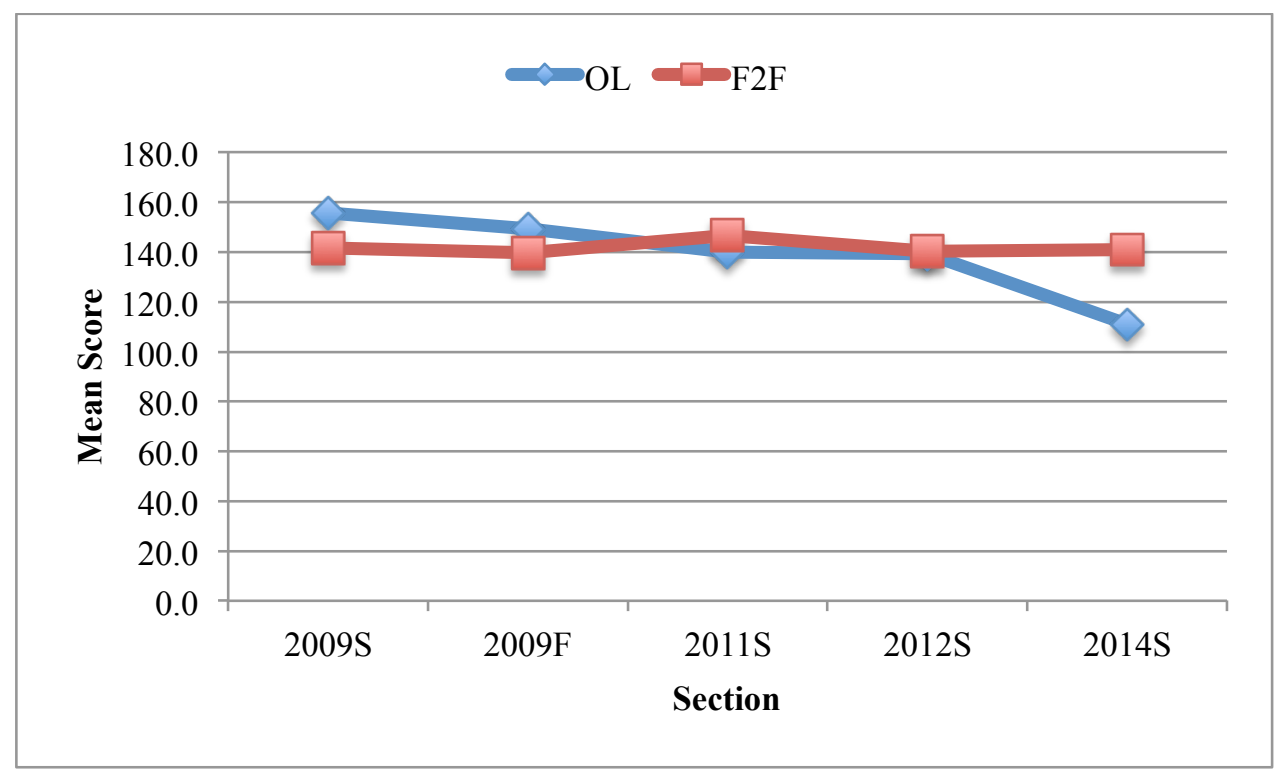

Figure 4 - H3. Management Use of Information

Finally, the fourth hypothesis tested whether online and face-to-face students have the same ability to interpret and analyze accounting information (see Figure 5). Online students scored lower $(\mathrm{M}=114.66)$ than face-to-face students $(\mathrm{M}=120.69)$, but the difference was not significant at the .05 critical alpha level; $\mathrm{t}(8)=1.01, \mathrm{p}=0.344$. Therefore we fail to reject the null hypothesis and conclude that the difference between online and face-to-face students was not significant. 


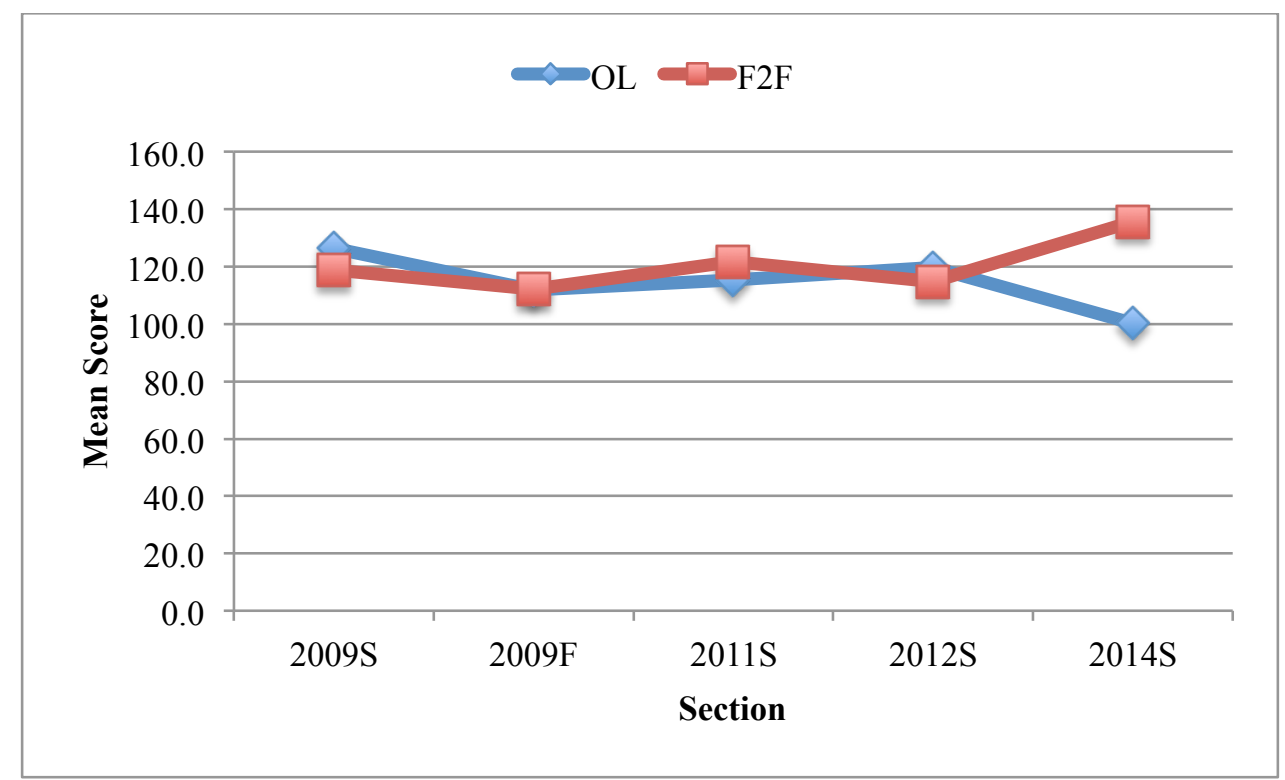

Figure 5 - H4. Interpret and Analyze Accounting Information

\section{LIMITATIONS}

As with most projects there are several limitations in this research, specifically:

- All of the students are from a single university. As a result it is very difficult to generalize the results beyond that single school

- The delineation of online versus face-to-face status is simply based on the capstone class the student selected. There is no guarantee that an "online" student completed her or his entire program in the online mode.

- The goals were established by a simulation vendor and as a result it was difficult to focus entirely on the initial research question. Although the main focus was the goal Interpret and Analyze Accounting Information we opted to include other data that seemed related (i.e. critical thinking, innovation, and technology). We accept there was a degree of mission creep; however, we believe the results will be of interest to the wider community.

\section{CONCLUSIONS}

The genesis of this project was the finding that that online students and face-to-face students performed at different levels in a goal of interpreting and analyzing accounting information. This preliminary finding was the spark for a project that considered five years of data. As the results section clearly illustrated, this initial finding was not supported by the more comprehensive study. Ultimately, the results of this study mirror those of many other studies that suggest online students and face-to-face students perform equally (Benton \& Cashin, 2012 and Drouin, 2012).

To some, this finding will be disappointing or even considered a failure as no new knowledge was to the body of knowledge. In fact, exactly the opposite is true. As researchers we have an obligation to report our findings even if they do not support our original hypotheses. To hide research that does not support our agenda is dishonest.

It was very clear from the responses that there were no significant differences in skills amongst online and face-toface students. This research reinforces previous research that supports the notion that there is not a statistically significant difference in learning between online and face-to-face students. Further, this research reminds educators that we must not jump to conclusions based on a single dataset, but rather must collect data over a number of periods before analysis 


\section{REFERENCES}

1. Allen, I.E., \& Seaman, J. (2014). Grade change: Tracking online education in the United States. Babson Survey Research Group and Quahog Research Group. Retrieved from http:// www.onlinelearningsurvey.com/reports/gradechange.pdf

2. Benton, S. L., \& Cashin, W. E. (2012). Student ratings of teaching: A summary of research and literature. Manhattan, KS: The IDEA Center. Retrieved from http://www.theideacenter.org/sites/default/files/ideapaper_50.pdf

3. Capsim (2013). CompXM: Assurance of Learning Guide. Chicago, Il.

4. Dawes, R. M. Rational Choice in an Uncertain World. Orlando, Fla.: Harcourt Brace, 1988.

5. Defining Critical Thinking. (2015, April 21). Retrieved from Foundation for Critical Thinking: http://www.criticalthinking.org/pages/defining-critical-thinking/410

6. Derwin, E. (2009). Critical thinking in online vs. face-to-face higher education. Media Psychology Review, 2(1). Retrieved from http://mprcenter.org/mpr

7. Drouin, M. (2012). What's the story on evaluations of online teaching? In M. E. Kite (Ed.), Effective evaluation of teaching: A guide for faculty and administrators (pp. 60-70). Washington, DC: Society for the Teaching of Psychology. Retrieved from http://www.teachpsych.org/Resources/Documents/ebooks/evals2012.pdf

8. Halpern, D. F. (1999). Teaching for Critical Thinking: Helping College Students Develop the Skills and Dispositions of a Critical Thinker. New Directions For Teaching \& Learning, 1999(80), 69.

9. Kim, K., Sharma, P., Land, S. M., \& Furlong, K. P. (2013). Effects of Active Learning on Enhancing Student Critical Thinking in an Undergraduate General Science Course. Innovative Higher Education, 38(3), 223-235. Retrieved from http://eds.b.ebscohost.com/eds/pdfviewer/pdfviewer?sid=38b2173f-7663-4b31-b34de18dd080eb19\%40sessionmgr115\&vid=0\&hid=104

10. King, A. (1995). Inquiring minds really do want to know: Using questioning to teach critical thinking. Teaching of Psychology, 22(1), 13-17.

11. Mayer, R. E. Thinking, Problem Solving, Cognition. New York: Freeman, 1992.

12. Moon, J. (2008). Critical thinking: An exploration of theory and practice. London and New York: Routledge, Taylor \& Francis Group.

13. Paul, R., \& Elder, L. (2006). A guide to critical thinking competency standards: Standards, principles, performance indicators, and outcomes with a critical thinking master rubric. Dillon Beach, CA: Foundation for Critical Thinking

14. Rabinowitz, M. (ed.). Cognitive Science Foundations of Instruction. Hillsdale, N.J.: Erlbaum, 1993.

15. Ricci, F. A. (2013). Encouraging Critical Thinking in Distance Learning. Distance Learning, 10(1), 1-15.

16. Ter-Stepanian, A. (2012). Online or Face to Face?: Instructional Strategies for Improving Learning Outcomes in e-Learning. International Journal of Technology, Knowledge \& Society, 8(2), 41-50. 